Вісник Дніпропетровського університету. Серія: геологія, географія. 25 (1), 2017, 101 - 118.

Vìsnik Dnìpropetrovs'kogo unìversitetu. Serìa Geologiâ, geographìâ

Dnipropetrovsk University Bulletin. Series: geology, geography. 25 (1), 2017, 101 - 118.

Doi: $10.15421 / 111712$

http://geology-dnu.dp.ua

УДК [561:581.33]:551.791(477)

\title{
Субаеральні відклади еоплейстоцену-нижнього неоплейстоцену рівнинної частини України та їх палінологічна характеристика
}

\section{О.А. Сіренко}

Інститут геологічних наук НАН Украӥни, Київ, Украӥна,

e-mail: o_sirenko@ukr.net

Розглянуто будову розрізу субаеральних відкладів плейстоцену рівнинної частини України. За результатами узагальнення матеріалів палеопедологічних $\mathbf{i}$ палінологічних досліджень еоплейстоценовихнижньонеоплейстоценових відкладів рівнинної України наведено літологічну та палінологічну характеристики кліматолітів еоплейстоцену-нижнього неоплейстоцену. Виявлено літологічні особливості відкладів кліматолітів у межах тектонічних структур України: Донецької складчастої споруди, Українського щита, Дніпровсько-Донецької та Причорноморської западин, Волино-Подільської плити та простежено регіональні особливості поширення еоплейстоценових $\mathbf{i}$ нижньонеоплейстоценових відкладів $\mathbf{y}$ межах зазначених регіонів. За результатами палінологічних досліджень відкладів 16 розрізів, розташованих в межах всіх сучасних рослинних зон України (лісової, лісостепової та степової) встановлено дев'ять спорово-пилкових комплексів, що характеризують еоплейстоценові-нижньонеоплейстоценові відклади рівнинної частини України. Для кожного кліматоліту встановлено таксономічний склад спорово-пилкових комплексів, їх тип (лісовий, лісостеповий, степовий) та характерні таксони. Простежено відміни таксономічного складу різновікових СПК. У складі комплексів виділені підкомплекси, які відповідають грунтам окремих стадій грунтоутворення (оптимальним і заключній) та малопотужним лесовидним прошаркам, що їх розділяють. Встановлено, що закономірності зміни підкомплексів у складі комплексу кожного кліматоліту індивідуальні та слугують основою для стратифікації та кореляції досліджених відкладів, а також є підставою для реконструкції фаз та підфаз розвитку рослинності. За результатами отриманих даних запропоновано зміни та доповнення до Модифікованої стратиграфічної схеми четвертинних відкладів України. На основі комплексних палінологічних та палеопедологічних досліджень обгрунтовано включення широкинського кліматоліту до еоплейстоцену. Запропоновано новий підхід до представлення палеоботанічних матеріалів і виконано палінологічне обгрунтування кліматолітів еоплейстоцену та нижнього неоплейстоцену до Модифікованої стратиграфічної схеми четвертинних відкладів.

Ключові слова: еоплейстоценові, нижньонеоплейстоцеові відклади, палеопедологія, палінологія, стратиграфія, Україна

\section{Subaeral Eopleistocene-Lower Neopleistocene deposits of the plain part of Ukraine and their palynological characteristic}

\section{O.A. Sirenko}

Institute of Geological Sciences NAS of Ukraine, Kiyv, Ukraine, e-mail: o_sirenko@ukr.net

The section structure of Pleistocene subaerial deposits of the plain part of Ukraine is considered. According to the results of generalization and analysis of paleopedological and palynological research of Eopleistocene - Lower Neopleistocene deposits of Ukraine the lithological and palynological characteristics of Eopleistocene - Lower Neopleistocene climatolites are presented. Lithological characteristics of the climatolites for each major tectonic region of Ukraine (Donetsk folded structure, Ukrainian Shield, Dnieper-Donets depression, Black Sea coastal depression, Volyn-Podolian Plate) are determined. Peculiarities of distribution of Eopleistocene - Lower Neopleistocene sediments within these regions are described. By the results of palynological research of 16 sections located within all modern vegetation zones (forest, forest-steppe and steppe) of Ukraine the nine spore-pollen complexes Eopleistocene-Lower Neopleistocene deposits of plain part of Ukraine are determined.For each climatolite the taxonomic composition of spore-pollen complexes, their type (forest, forest-steppe or steppe) and specific taxa are established. Peculiarities of the taxonomic composition of complexes of different age were traced. Subcomplexes are distinguished within in the composition of the complexes. These subcomplexes correspond to the soils of separate stages of soil formation and loessal interbeds of low thickness. Regularities of subcomplexes changes in complex of each climatolites are individual and are also a basis for stratification and correlation of the deposits and reason 
for reconstruction vegetation development phases and subphases. Based on the data obtained, the changes and additions to the modified Stratigraphic Scheme of Quaternary deposits of Ukraine are proposed. On the basis of complex palynological and palaeopedological studies, the inclusion of the Shyrokinsky climatolith in the Eopleistocene are justified. A new approach to representation of paleobotanical materials are proposed. The palynological ground of the Eopleistocene and Lower Neoplestocene climatolits to the modified Stratigraphic Scheme of Quaternary deposits of Ukraine has been made. Keywords: Eopleistocene, Lower Neopleistocene deposits, paleopedology, palynology, stratigraphy, Ukraine

Вступ. На значній частині території України відклади плейстоцену представлені переважно субаеральними породами - викопними грунтами, лесами та лесоподібними суглинками, тому велике значення у їх вивченні мають комплексні палеопедологічні та палінологічні дослідження. Палеопедологічні матеріали до характеристики плейстоценових відкладів України представлені у багатьох публікаціях, до основних із яких можливо зарахувати такі (Veklich, Sirenko, 1976, Veklich, 1982, Veklich, Sirenko, Matviishina, 1984, Sirenko, Turlo, 1986, Shelkopljas, Gozhik, Hristoforova, 1986).$$
\text { у зв'язку }
$$
широкомасштабних робіт за програмою «Держгеолкарта-200» та створенням Стратиграфічної схеми четвертинних відкладів України нового покоління виникла необхідність проведення додаткових палеопедологічних та палінологічних досліджень у регіонах із недостатньою вивченістю відкладів плейстоцену та деталізації літологічної та палеоботанічної характеристик порід у розрізах, вивчених на ранніх етапах формування поглядів на четвертинну стратиграфію.

На попередніх етапах палінологічних досліджень у зв'язку 3 відсутністю якісних лабораторних методик виділення паліноморф із субаеральних порід у мацератах зразків містилось дуже мало пилку та спор, що не дозволяло підраховувати кількісні показники окремих таксонів у складі спорово-пилкових спектрів та будувати спорово-пилкові діаграми. Також приділялось мало уваги детальності відбору зразків. Інколи педогоризонт або лес були охарактеризовані спорово-пилковими спектрами одного чи двох зразків, що не давало можливості виконувати детальні палеофлористичні реконструкції та стратиграфічні побудови. На сучасному етапі досліджень існує багато методик екстрадиції паліноморф із порід, що дозволяє проводити дослідження на більш високому рівні.

Незважаючи на достатньо тривалу історію палінологічних досліджень плейстоценових відкладів України, породи еоплейстоцену та нижнього неоплейстоцену виявились найменш охарактеризованими, особливо у розрізах, розташованих у межах сучасних лісостепової та лісової зон. У той же час, вивчення цих відкладів - ключове завдання для палінологічного обгрунтування границь пліоцен - плейстоцен, еоплейстоцен - нижній неоплейстоцен, нижнійсередній неоплейстоцен.

Слід наголосити, що результати палінологічних досліджень континентальних плейстоценових відкладів України до недавнього часу послуговували переважно для палеогеографічних та палеоботанічних реконструкцій (Artjushenko, 1970, Artjushenko, Pashkevich, Parishkura, Kareva, 1973, Gerasymenko, 2004, Matviishyna, Gerasymenko, Perederii, Brahin, Ivchenko, Karmazynenko, Nahirnyi, Parkhomenko, 2010, Sirenko, Turlo, 1986) і практично не використовувались для стратиграфічних цілей. Зазначимо, що в жодній 3 публікацій стосовно палінологічних досліджень еоплейстоценових та неоплейстоценових відкладів України не було наведено узагальнену палеоботанічну характеристику кліматолітів, тому репрезентована робота $€$ піонерною у цьому напрямку. Таким чином, основна метою цієї роботи - узагальнення особистих та літературних матеріалів щодо літологічної та палінологічної характеристик еоплейстоценовихнижньонеоплейстоценових відкладів України 3 урахуванням критеріїв паліностратиграфії, розроблених автором (Sirenko, 2011), для отримання палеоботанічної характеристики кліматолітів еоплейстоцену-нижнього неоплейстоцену для більш широкого впровадження результатів спорово-пилковаго аналізу в практику геолого-знімальних робіт. Нові узагальнені палеопедологічні матеріали дозволять більш надійно стратифікувати плейстоценові відклади регіонів дослідження.

Матеріал та методи досліджень. Автором палінологічно вивчені еоплейстоценові та нижньонеоплейстоценові відклади у 16 розрізах (рис.1), розташованих у межах Донецької складчастої споруди, Дніпровсько-Донецької (ДД3) та Причорноморської западин (Sirenko, 1994, 2012), центральної, північної та південної частин Українського щита (УЩ) (Sirenko, 2002, 2009a, Sirenko, Bahmutov, Nikitchenko, 2008), a також Волино-Подільської плити (Sirenko, 
2009b), i, відповідно, - в межах трьох сучасних рослинних зон: степової, лісостепової і мішаних лісів. Варто зазначити, що еоплейстоценові та нижньонеоплейстоценові відклади північної частини УЩ (Житомирське Полісся) та ВолиноПодільської плити палінологічно вивчені автором уперше для території України. У процесі складання літологічної характеристики використано особисті матеріали автора за результатами вивчення численних розрізів (свердловин i відслонень) четвертинних відкладів, отриманих прід час виконнання програми «Держгеолкарта-200», а також матеріали В. Д. Возгріна та частково Н. О. Сіренко, у співдружності 3 якими виконувалась стратифікація значної кількості розрізів для палінологічних досліджень.

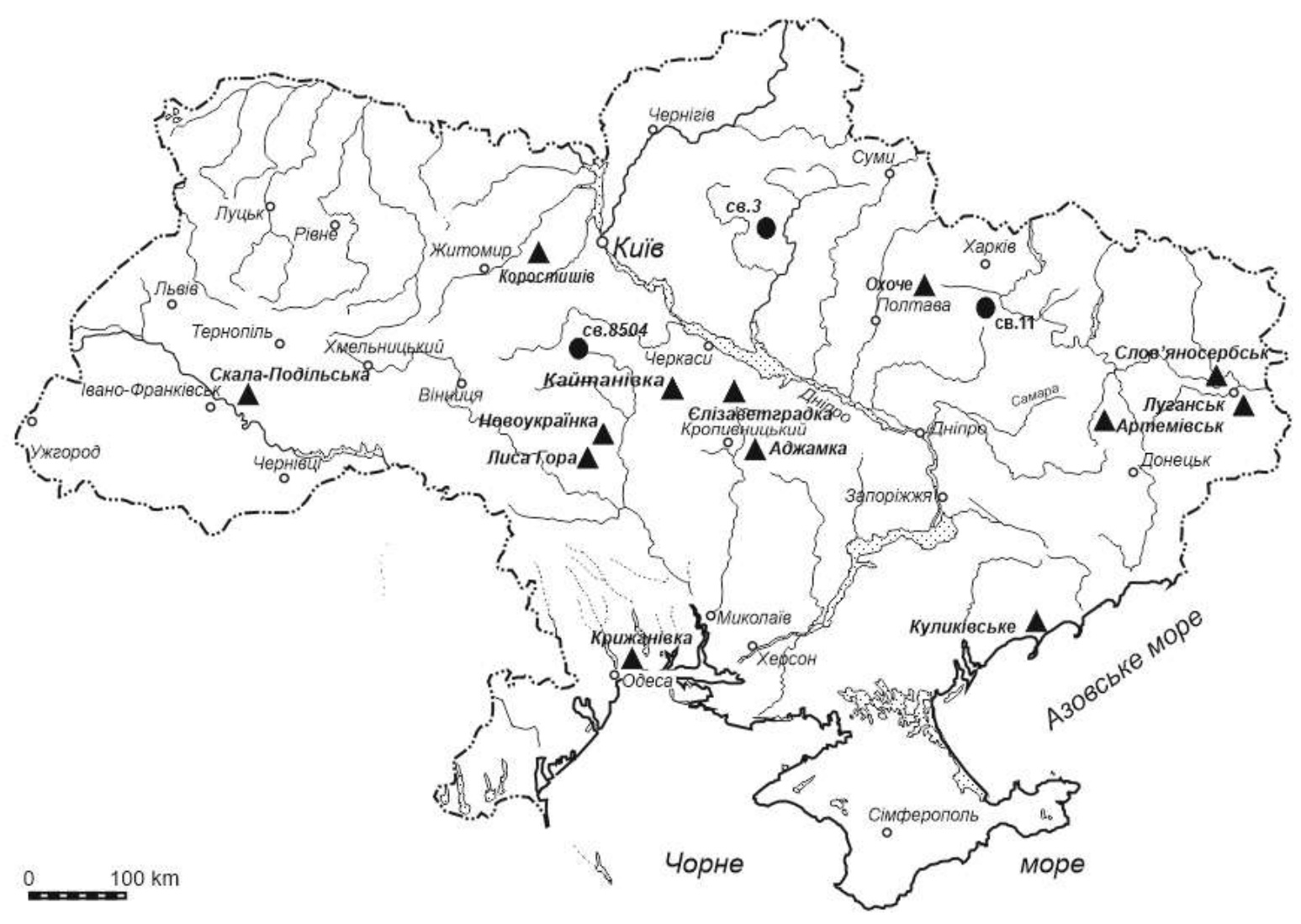

Рис. 1. Схема розташування розрізів, у яких палінологічно вивчені відклади еоплейстоцену та нижнього неоплейстоцену.

Основним методом досліджень був спорово-пилковий аналіз. У зв'язку з тим, що необхідною умовою вивчення верхньокайнозойських субаеральних порід методом спорово-пилкового аналізу та правильної інтерпретації отриманих матеріалів $є$ врахування будови педогоризонтів i лесових горизонтів, а також закономірностей їх формування (Sirenko, 2012), палінологічні дослідження проводились у комплексі 3 палеопедологічними.

Найбільшу увагу у статті приділено відкладам еоплейстоцену та нижнього неоплейстоцену УЩ, оскільки в межах різних частин зазначеного регіону за останні роки вивчено найбільшу кількість розрізів (рис.1). Для стратиграфічного розчленування плейстоценових порід використана Стратиграфічна схема континентальних четвертинних відкладів України 1993 р. (Stratigraficheskie skhemy dokembriya i fanerozoya Ukrainy, Redaktor Volodin, 1993), згідно з якою до еоплейстоцену відносяться березанський, крижанівський та іллічівський кліматоліти. Беручи до уваги результати комплексних палінологічних і палеопедологічних досліджень, до еоплейстоцену віднесено також широкинський кліматолит. Згідно 3 
доповненнями до Схеми 1993 p. (Stratygrafichnyj kodeks Ukrai'ny, Redaktor Gozhyk, 2012), до еоплейстоцену віднесено також і приазовський кліматоліт, але у наведеній статті він розглядається як нижньонеоплейстоценовий. У складі нижнього неоплейстоцену розглядаються також мартоноський, сульський, лубенський та тилігульський кліматоліти. Нижня межа четвертинної системи, згідно Стратиграфічного кодексу України (Stratygrafichnyj kodeks Ukrai'ny, Redaktor Gozhyk, 2012) прийнята на рівні 1,8 млн років.

Основні результати. Наведено узагальнену характеристику еоплейстоценових нижньонеоплейстоценових відкладів регіонів дослідження та коротку літологічну характеристику кліматолітів і їх палінологічне обгрунтування.

Український щит. Плейстоценові відклади УЩ складені утвореннями трьох формацій: рівниннольдовикової, лесової та частково червонобуроколірної. Породи, що належать до рівниннольодовикової формації, поширені переважно в межах північно-західної частини регіону (Полісся). Найбільш представницькі відклади лесової формації, що розвинуті в межах усіх частин УЩ, а особливо - центрального та південного регіону. Породи червонобуроколірної формації, що належать до еоплейстоцену, інколи поховані утвореннями лесової та рівнинно-льодовикової формацій. Фаціальний склад та потужності плейстоценових відкладів у межах УЩ не витримані по площі. Їх потужність зафіксована в межах від 1 до 60 м.

Характерна риса неоплейстоцену України - це присутність морен - свідчень материкових зледенінь. У межах регіону досліджень зустрічаються льодовикові відклади середньонеоплейстоценового дніпровського зледеніння. Відомі матеріали стосовно того, що у північно-західній частині регіону досліджень, у басейні p. Горинь зрідка простежуються нижньонеоплейстоценові водно-льодовикові утворення, на які накладені більш молоді (дніпровські) льдовикові відклади (Shovkopljas, Vozgrin, Hristoforova, 2011).

Зазначеним двом максимальним зледенінням у центральній та південній частинах регіону досліджень відповідають два найбільш потужні лесові горизонти - сульский та дніпровський.

Еоплейстоцен. $\mathrm{y}$ субаеральних фаціях еоплейстоценові відклади частіше за все представлені викопними грунтами коричнево- бурими, червонувато-бурими, інколи сизуватосірими глинистого гранулометричного складу та буроколірними лесоподібними глинами, що їх розділяють. Еоплейстоценові відклади доволі широко розвинуті на плакорах лесової області, а в межах Українського Полісся поширені фрагментарно. Вони зустрічаються у південнозахідній частині Київського Полісся (м. Фастів, с. Музичі), на південному сході та південному заході Житомирського Полісся (м. Коростишів, м. Дзержинськ).

У північній частині УЩ еоплейстоценові відклади частіше за все залягають на розмитій поверхні еоплейстоцену, неогену, палеогену та крейди. Присутні також декілька поясів крайових льодовикових утворень, воднольодовикових морфоструктур (камів, о3, льодовикових поверхонь вирівнювання i розмиву, водно-льодовикових долин). Для розрізів Українського Полісся типове залягання під сучасним грунтом дніпровської морени, або піщаних утворень. Найбільш повні розрізи розташовані на понижених елементах дочетвертинного рельєфу. Характерна риса плейстоценових відкладів Полісся - це їх сильний гідроморфізм, тому у їх забарвленні переважають темно-сизі, темно-сірі та зеленувато-сірі кольори. Потужність еоплейстоценових відкладів складає $0,5-5,0$ м. Відклади еоплейстоцену належать переважно до епохи оберненої полярності Матуяма.

Коротка літологічна характеристика кліматолітів.

Березанський та іллічівський

кліматоліти - представлені глинами та важким суглинками бурувато-сірого та зеленувато-сірого кольру, інколи 3 малопотужними прошарками ембріональних викопних грунтів. Потужність кожного 3 кліматолітів зазвичай не перевищує 1 м. У розрізах регіону досліджень часто редуковані.

Крижсанівський кліматоліт представлений педогоризонтом, який складається 3 трьох викопних грунтів: раннього $\left(\mathrm{kr}_{\mathrm{b} 1}\right)$, пізнього $\left(\mathrm{kr}_{\mathrm{b} 2}\right)$ оптимумів та заключної стадії педогенезу $\left(\mathrm{kr}_{\mathrm{c}}\right)$, червонувато-бурих, червонувато-коричнево-бурих, світлокоричневих, глинистих за гранулометричним складом. У нижній та середній частинах педогоризонту зустрічаються дрібні та середні за розміром карбонатні стяжіння. Для південної частини регіону характерні переважно червонувато-бурі викопні грунти, значною 
Таблиия

Палінологічне обгрунтування Стратиграфічної схеми четвертинних (еоплейстоцен-нижній неоплейстоцен) відкладів України (проект)

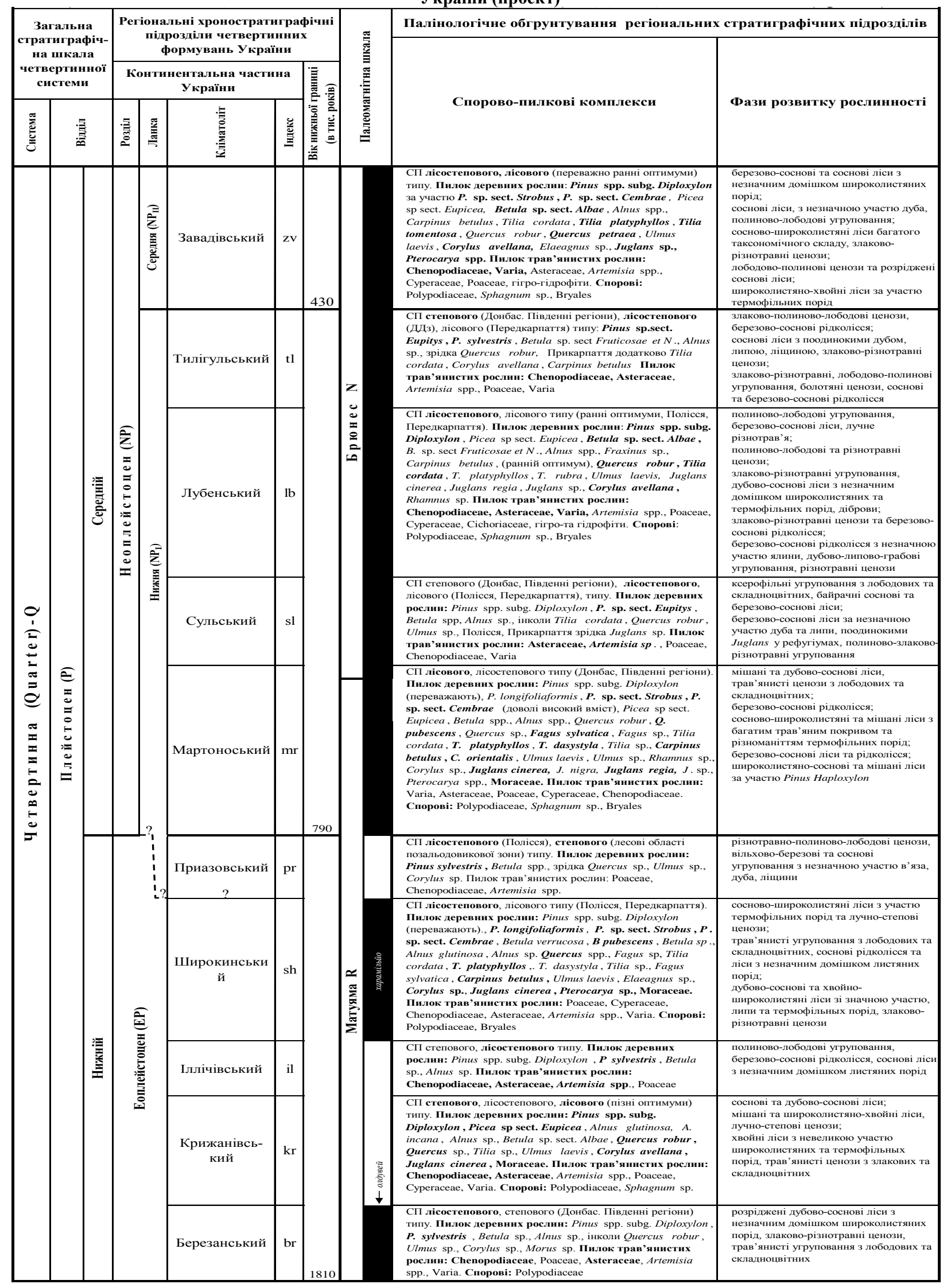


мірою загіпсовані. Потужність педогоризонту складає $0,5-4,0 \mathrm{M}$.

Широкинський кліматоліт - у субаеральній фації представлений педогоризонтом, що складається переважно 3 двох викопних грунтів раннього $\left(\mathrm{sh}_{1}\right)$ та пізнього оптимумів $\left(\mathrm{sh}_{3}\right)$ дерново-глейових, лугових у північно-західній частині регіону, коричневих, червонувато- і темнокоричневих - у центральній частині регіону, червонувато-коричневих і коричневих засолених - на півдні. У переважній більшості розрізів центральної частини регіону зустрічається лише пізньооптимальний грунт $\mathrm{sh}_{3}$. За гранулометричним складом грунти глинисті, що відрізняє їх від нижньонеоплейстоценових мартоноських грунтів. За структурою переважно горіхувато-призматичні. Для нижньої частини профілю ранньооптимального грунту характерні великі (до 10 см у діаметрі) кремнистокарбонатні конкреції, нижня границя нерівна 3 потьоками грунтового матеріалу. Потужність педогоризонту складає $0,5-3,0$ м.

\section{Нижній неоплейстоцен.}

Нижньонеоплейстоценові відклади регіону досліджень мають переважно елювіальний (викопні грунти), еоловий, еолово-делювіальний (леси та лесоподібні суглинки) й алювіальний (субаквальні відклади річкових долин) генезис.

За матеріалами Н. О. Сіренко (Sirenko, Turlo, 1986), нижньонеоплейстоценові викопні грунти в північній частині регіону мають темносірий, темно-буро-сірий колір, бурий, коричнювато-бурий, коричнювато- та коричнево-сірий колір у центральній частині та червонувато-бурий і червонувато-коричневий - у південній. Лесові та лесоподібні відклади відрізняються палевим і буро-палевим кольором, інколи із зеленуватим відтінком.

Гранулометричний склад субаеральних нижньонеоплейстоценових відкладів змінюється від супісків до суглинків та глин. Слід зазначити, що важкосуглинистий та глинистий гранулометричний склад найбільш характерний для педогоризонтів, порівняно до відкладів, що сформувались у холодні етапи. На денну поверхню відклади нижнього неоплейстоцену інколи виходять у бортових частинах річкових долин та балок, на плакорах простежуються у розрізах кар'єрів. Потужність нижньонеоплейстоценових відкладів складає від 1,0 до 20,0 м, у середньому $-5,0-10,0$ м.

За даними палеомагнітних досліджень (Sirenko, Bahmutov, Nikitchenko, 2008) лесовогрунтових відкладів, границя епох прямої полярності (Брюнес) та оберненої полярності (Матуяма) у більшості розрізів простежена у відкладах мартоноського кліматоліту. Проте, слід зазначити неоднозначну трактовку різними дослідниками положення границі БрюнесМатуяма у розрізах плейстоценових відкладів України. Так, у розрізах, вивчених O. Н. Третяком (Tretjak, Vigiljanskaja, 1994), зазначена границя відповідає покрівлі нижнього викопного грунту широкинського педогоризонту. Результати досліджень В. Г. Бахмутова свідчать про проведення цієї границі у верхній частині мартоноського педогоризонту (Sirenko, Bahmutov, Nikitchenko, 2008). Остання точка зору на сучасному етапі досліджень найбільш поширена серед магнітологів.

\section{Приазовський кліматоліт - у}

субаеральних фаціях представлений суглинками буро-палевими, лесоподібними, середніми до важких, пилуватими за гранулометричним складом. Потужність складає 0,2 - 3,9 м. У більшості розрізів приазовські лесоподібні породи відсутні i грунти мартоноського педогоризонту розташовані безпосередньо на широкинських. Відклади відносять до епохи оберненої полярності Матуяма.

$\begin{array}{ccc}\text { Мартоноський кліматоліт - } & \text { у } \\ \text { субаеральних } & \text { фаціях }\end{array}$ педогоризонтом, що складається із трьох грунтів - раннього $\left(\mathrm{mr}_{\mathrm{b} 1}\right)$, пізнього $\left(\mathrm{mr}_{\mathrm{b} 2}\right)$ оптимумів та заключної стадії педогенезу - $\mathrm{mr}_{\mathrm{c}}$. Слід зазначити, що у більшості розрізів центральної частини регіону простежується лише один або два грунти. Частіше за все це грунти пізнього оптимуму та заключної стадії педогенезу, інколи раннього та пізнього оптимумів.

Грунти у північній та центральній частинах регіону бурі, червонувато- та коричнювато-бурі, а в південній частині червонувато-коричнево-бурі. Грунти переважно важкосуглинистого гранулометричного складу, злиті, крупногрудкуватої та глибистої структури. $\mathrm{y}$ деяких розрізах відмічені прояви процесів кріогенезу наступних зледенінь: клиноподібні псевдоморфози, жили, тріщинуватість, прояви соліфлюкції. Загальна потужність педогоризонту $0,4 \quad-4,5$ м. Мартоноські відклади характеризуються як прямою, так і оберненою намагніченістю, а границя ортозон Брюнес i Матуяма приурочена переважно до верхньої частини кліматоліту (Sirenko, Bahmutov, Nikitchenko, 2008). 
Сульський кліматолім - у субаеральних фаціях представлений лесоподібним суглинком, оливково-палевого кольору, пилуватим за складом, інколи супіском та піском. Потужність зазвичай складає 0,2-4,0 м, але може сягати і 13 м. Найбільші потужності характерні для відкладів розрізів Середнього Придніпров'я та Верхнього Побужжя. Сульські відклади сформовані в епоху прямої полярності Брюнес (Sirenko, Bahmutov, Nikitchenko, 2008).

Лубенський кліматоліт - у субаеральних фаціях представлений педогоризонтом, який у повних розрізах складається 3 трьох викопних грунтів. Грунти раннього оптимуму $\left(\mathrm{lb}_{\mathrm{b} 1}\right)$ у північній частині регіону бурі та сірі лісові, у центральній та південній частинах червонувато-бурі, бурувато-коричневі, червонувато-коричневі. Згідно 3 отриманими нами матеріалами, у складі лубенського кліматоліту розрізів регіону досліджень можуть простежуватись два грунти пізнього оптимуму $\left(\mathrm{lb}_{\mathrm{b} 2}\right)$. Нижні грунти пізнього оптимуму у північній та центральній частинах регіону лугово-чорноземоподібні, чорноземоподібні, вилуговані від карбонатів, на півдні - коричневі і червонувато-коричневі. Верхні грунти пізнього оптимуму i заключної стадії педогенезу у північній частині регіону бурі лісові та буруватокоричневі - в центральній та південній частинах. $\mathrm{y}$ деяких розрізах зустрічаються грунтові відклади лубенського віку. За гранулометричним складом грунти педогоризонту переважно важкосуглинисті, інколи - середньосуглинисті. Потужність педогоризонту складає 0,5-4,2 м. Породи лубенського кліматоліту характеризуються прямою та аномальною намагніченістю та сформувались в епоху прямої полярності Брюнес.

\begin{tabular}{lrr}
\multicolumn{2}{c}{ Tилігульський } & кліматоліт - завершує \\
розріз нижнього & неоплейстоцену. В
\end{tabular} субаеральних фаціях представлений суглинками лесоподібними, пилуватими, легкими і середніми за гранулометричним складом, а також супісками. Потужність 0,2- 5,0 м. У деяких розрізах відклади тилігульського кліматоліту можуть бути редуковані, в такому разі завадівський педогоризонт безпосередньо перекриває лубенський педогоризонт i формується єдиний грунтовий комплекс.

Вище у неоплейстоценовому розрізі тилігульські відклади перекриваються педогоризонтом середньонеоплейстоценового завадівського кліматоліту. Стратотип цього педогоризонту розташований в межах регіону досліджень на межиріччі pp. Рось та Вільшанка біля с. Завадівка.

Волино-Подільська плита. Згідно зі схемою районування четвертинних відкладів України (Stratigraficheskie skhemy dokembriya i fanerozoya Ukrainy, Redaktor Volodin, 1993) регіон досліджень належить до північно-західної лесової області. Плейстоценові відклади розповсюджені доволі широко, загальна потужність їх перебуває в межах 25-30 м. Представлені утвореннями алювіального, льодовикового, водно-льодовикового, еолового, елювіального та делювіального генетичних типів. У зв'язку 3 особливостями геоморфлогічноі будови Поділля плейстоценові відклади цього регіону характеризуються невитриманістю поширення по латералі, доволі незначною потужністю, переважним розвитком делювіальних фацій. В межах окремих територій (круті денудаційні ділянки схилів у ГологороКременецькому низькогірному краї Поділля, в каньйоні біля р. Дністер та ділянках його лівих подільських притоків - Збруча, Серета, Стрипа та ін. та на верхів'ях Товтрової гряди, окремих ділянках Малого Полісся плейстоценові відклади відсутні (Shelkopljas, Gozhik, Hristoforova, 1986).

Стратифікація плейстоценових відкладів часто ускладнена через порушення послідовності напластування. Характерна риса розрізу плейстоценових відкладів регіону досліджень найбільш широке представництво порід середнього та верхнього неоплейстоцену. Еоплейстоценові та нижньонеоплейстоценові відклади зустрічаються не скрізь, особливо в субаеральній фації і у більшості розрізів представлені пісками, галечниками, супісками та гідроморфними грунтами. Підстилаються алювіальними породами верхнього пліоцену, а частіше за все - неогеновими відкладами (переважно сарматськими). Перекриваються субаеральними породами середнього неоплейстоцену (лесоподібними суглинками та супісками), або бурими та жовтувато-бурими середньонеоплейстоценовими викопними грунтами. Найбільш представницькі розрізи нижньонеоплейстоценових субаеральних відкладів розташовані на річкових терасах у межах Придністровського Поділля. У зв'язку 3 тим, що еоплейстоценові та нижньонеоплейстоценові відклади в межах зазначеного регіону вивчені нами палеопедологічно і палінологічно лише в одному розрізі, узагальнену характеристику кліматолітів не наводимо. Детальна характеристика 
еоплейстоценових та неоплейстоценових відкладів Волино-Подільської плити наведена у працях А. Б. Богуцького зі співавторами (Boguckij, 1987, Boguc'kij A.B., Boguc'ki, Voloshin, 1998.).

Причорноморська западина. Найбільш широко в межах регіону досліджень представлені субаеральні відклади еоплейстоцену та неоплейстоцену, алювіальні відклади займають менші площі. Потужність субаеральних відкладів коливається в межах 15 м, а інколи сягає 40 м і представлені вони червоноколірними викопними грунтами та лесами і лесоподібними суглинками, що їх розділяють.

Згідно зі схемою районування четвертинних відкладів України (Stratigraficheskie skhemy dokembriya i fanerozoya Ukrainy, Redaktor Volodin, 1993), регіон досліджень належить до південної лесової області позальодовикової зони.

Максимальні потужності субаеральних відкладів приурочені до берегової зони моря, 3 віддаленням від неї завдяки процесам денудації потужності скорочуються. У підошві континентальних плейстоценових відкладів залягають породи міоцену (понту) i верхнього пліоцену (куяльнику). В межах різних частин регіону змінюються потужності та представництво у розрізах відкладів лесовогрунтової формації. В північній частині регіону розріз субаеральних відкладів значно скорочений (Shelkopljas, Gozhik, Hristoforova, 1986), особливо за рахунок нижньонеоплейстоценових порід. У розрізах північно-східної та західної частин представлені всі кліматоліти плейстоцену, за винятком приазовського.

Коротка літологічна характеристика кліматолітів.

Еоплейстоцен. Березанський кліматолім складений глинами, суглинками, супісками, інколи 3 малопотужними викопними грунтами. Загальна потужність 0,3-2,0 м.

\section{Крижанівський кліматоліт}

представлений педогоризонтом, який складається 3 двох викопних грунтів кліматичних оптимумів $\left(\begin{array}{lll}\mathrm{kr}_{\mathrm{b} 1} & \left.\mathrm{kr}_{\mathrm{b} 2}\right) & \text { та грунту }\end{array}\right.$ заключної стадії $\mathrm{kr}_{\mathrm{c}}$. Грунти червонуватокоричневі $\left(\mathrm{kr}_{\mathrm{b} 1}\right)$ та червонувато-бурі $\left(\mathrm{kr}_{\mathrm{b} 2}\right)$, зазвичай гідроморфні, глинистого складу. Загальна потужність педогоризонту 0,5-2,0 м.

Іллічівський кліматоліт - складений сизувато-сірими лесоподібними суглинками та супісками. Потужність 0,1-1,5 м.

\section{Широкинський кліматолім}

представленний педогоризонтом, який складається 3 двох викопних грунтів. Грунти темно-коричневі, червонувато-коричневі $\left(\mathrm{sh}_{1}\right)$ та бурувато-коричневі $\left(\mathrm{sh}_{3}\right), \quad$ глинистого гранулометричного складу. Загальна потужність 1,0-3,0 м.

Нижній неоплейстоцена. Приазовський кліматоліт - складений лесоподібними суглинками та супісками, майже не простежується в розрізах. Потужність 0,0-0,1 м.

\section{Мартоноський кліматоліт -}

представлений педогоризонтом, який складається 3 трьох викопних грунтів та лесовидного прошарку, що розділяє грунти раннього та пізнього оптимумів. Грунти червонувато-коричневі та червонувато-бурі $\left(\mathrm{mr}_{\mathrm{b} 1}\right.$ , $\left.\mathrm{mr}_{\mathrm{b} 2}\right)$, а також бурі $\left(\mathrm{mr}_{\mathrm{c}}\right)$, важкосуглинисті за гранулометричним складом. Загальна потужність 0,2-3,0 м.

Сульський кліматоліт - складений оливково-палевими лесами, лесоподібними суглинками, супісками. Зрідка у лесовій товщі простежуються викопні грунти. Загальна потужність 0,5-6,5 м.

Лубенський кліматоліт - представлений педогоризонтом, який складається 3 трьох викопних грунтів коричнювато-бурих та червонувато-бурих $\left(\mathrm{lb}_{\mathrm{b} 1}\right)$, коричневих $\left(\mathrm{lb}_{\mathrm{b} 2}\right)$ i бурувато-коричневих $\left(\mathrm{lb}_{\mathrm{bc}}\right)$ середньо- та важкосуглинистих за гранулометричним складом. Загальна потужність 0,5-6,5 м.

Тилігульский кліматолит - складений сірувато-жовтими лесами, лесовидними суглинками, супісками. Загальна потужність $0,1-$ 5,0 м.

Дніпровсько-Донецька западина Північнозахідна частина Придніпровської низовини. Згідно зі схемою районування четвертинних відкладів (Stratigraficheskie skhemy dokembriya i fanerozoya Ukrainy, Redaktor Volodin, 1993), територія досліджень належить до північної області дніпровського льодовикового язика. Потужність плейстоценових відкладів зафіксована в межах від 50 до 90 м. Характерна особливість неоплейстоценового розрізу регіону досліджень - значне представництво відкладів холодних етапів, особливо тилігульського, дніпровського та бузького. Найбільшу потужність (до 30 м у субаеральному розрізі та 70 м - у субаквальному) мають відклади дніпровського кліматоліту, представленого, на відміну від суміжних регіонів, не лише лесоподібними суглинками, а і мореною. Серед 
відкладів теплих етапів найбільшу потужність має завадівський педогоризонт середнього неоплейстоцену. У підошві еоплейстоценових та нижньонеоплейстоценових відкладів містяться породи як верхнього пліоцену, так і верхнього олігоцену, у покрівлі середньонеоплейстоценовий завадівський кліматоліт.

Коротка літологічна характеристика кліматолітів.

Еоплейстоцен. Березанський кліматоліт - у субаеральних фаціях представлений світлосірими глинами, зрідка важкими суглинками та супісками. У найбільш повних розрізах у товщі лесоподібних суглинків простежуються декілька малопотужних ембріональних грунтів. Загальна потужність 0,5-3 м. Слід зазначити, що у розрізах найбільш представницькими $\epsilon$ субаквальні відклади кліматоліту, складені пісками та супісками, загальною потужністю 1,0-10,0 м.

\section{Крижанівський кліматоліт}

представлений педогоризонтом, складеним переважно із двох, зрідка - трьох викопних грунтів. Грунти бурого, червонувато-бурого, коричневого кольору, глинисті за гранулометричним складом, злиті, ущільнені, 3 гніздами борошнистих карбонатів та невеликими карбонатними конкреціями у нижній частині профілю. Потужність 1,0-6,0 м.

Іллічівський кліматоліт - складений сизувато-сірими, сірими глинами, зрідка лесовидними суглинками. Інколи у розрізах простежується декілька малопотужних ембріональних грунтів. Загальна потужність 0,55,0 M.

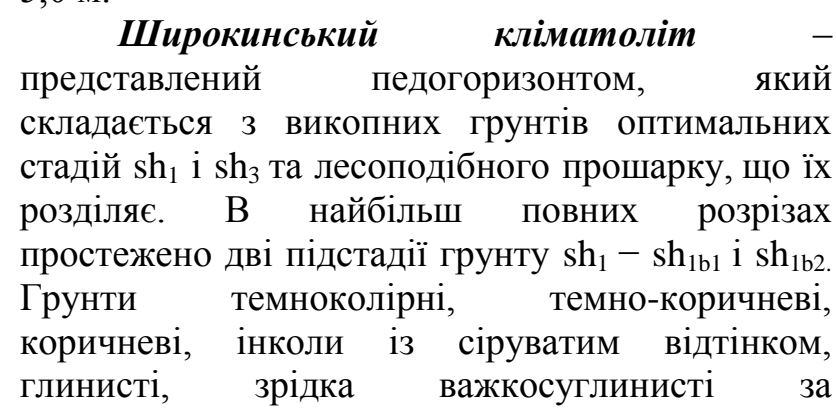
гранулометричним складом, оскольчатої, грудкуватої та дрібногрудкуватої структури. Загальна потужність 1,0-3,0 м.

Нижній неоплейстоцен. Приазовський кліматоліт - складений лесовидними суглинками важкими за гранулометричним складом. Зустрічається фрагментарно не у всіх розрізах. Потужність $0,0-4,0 \mathrm{M}$.

\section{Мартоноський}

кліматолім

представлений педогоризонтом, що складається переважно 3 двох викопних грунтів раннього $\left(\mathrm{mr}_{\mathrm{b} 1}\right)$ та пізнього $\left(\mathrm{mr}_{\mathrm{b} 2}\right)$ оптимумів, в найбільш представницьких розрізах простежується грунт заключної стадії педогенезу - mr. Часто грунти раннього та пізнього оптимумів розділені малопотужним $(0,2-0,3 \quad$ м $)$ лесоподібним суглинком. Грунти коричневі із червонуватим відтінком, червонувато- i коричнювато-бурі, важкосуглинистого гранулометричного складу, інколи - середньосуглинисті. Загальна потужність 1,0-5,0 м.

Сульський кліматолім - складений жовтувато-палевими, палево-жовтими лесоподібними суглинками, середньо- та важкосуглинистими, карбонатними. Загальна потужність 0,5-6,0 м.

Лубенський кліматоліт - у субаеральних фаціях представлений педогоризонтом, який складається із двох викопних грунтів оптимумів та грунту заключної стадії педогенезу, в найбільш представницьких розрізах, розділених малопотужними лесовими прошарками. Грунти раннього оптимуму $\left(\mathrm{lb}_{\mathrm{b} 1}\right)$ бурі лісові, пізнього оптимуму $\left(\mathrm{lb}_{\mathrm{b} 2}\right)$ - чорноземовидні, заключної стадії педогенезу - світло-бурі. За гранулометричним складом грунти переважно середньосуглинисті. Загальна потужність 1,0 4,0 м.

Тилігульський кліматоліт - складений лесами та лесоподібними суглинками палевими, інколи 3 жовтуватим відтінком, середніми та легкими за гранулометричним складом. У деяких розрізах у лесовій товщі простежуються ембріональні грунти. Загальна потужність 1,0-20,0 м.

Як уже зазначалось вище, нижньонеоплейстоценові відклади перекриває завадівський педогоризонт середнього неоплейстоцену, який $\epsilon$ найбільш представницьким, порівняно 3 розрізами суміжних регіонів. Простежуються два викопних грунти оптимумів завадівського педогенезу, чорноземоподібні, бурі та червонувато-бурі за кольором, а також орільський лес та коричневобурий потягайлівський грунт. Загальна потужність педогоризонту 1,5-15 м.

Слід зазначити, що у Стратиграфічній схемі четвертинних відкладів $1993 \mathrm{p}$. (Stratigraficheskie skhemy dokembriya i fanerozoya Ukrainy, Redaktor Volodin, 1993) орільський лес та потягайлівський грунт були включені до складу завадівського кліматоліту, а у Схемі, 
представленій у Стратиграфічному кодексі 2012 p. (Stratygrafichnyj kodeks Ukrai'ny, Redaktor Gozhyk, 2012), виділені як окремі стратони.

Центральна частина Придніпровської низовини Згідно зі схемою районування четвертинних відкладів (Stratigraficheskie skhemy dokembriya i fanerozoya Ukrainy, Redaktor Volodin, 1993) територія досліджень належить до північної лесової області позальодовикової зони. Залежності від геоморфологічної експозиції загальна потужність плейстоценових відкладів перебуває в межах від 10 до 50 м. Найбільш представницькі відклади еоплейстоцену та нижнього неоплейстоцену. Горизонти викопних грунтів, порівняно 3 лесовими, мають більшу потужність, яка складає $60-70 \%$ загальної потужності розрізів. Деякі горизонти лесоподібних глин та суглинків, зокрема, іллічівський, березанський, приазовський часто редуковані. Еоплейстоценові та нижньонеоплейстоценові відклади в розрізах згідно залягають на верхньопліоценових i перекриваються середньонеоплейстоценовими грунтами завадівсьго кліматоліту. Алювіальні відклади мають обмежене поширення.

\section{кліматолітів.}

Коротка літологічна характеристика

Еоплейстоцен Березанський кліматоліт субаеральні відклади складені сизувато-жовтобурими глинами та важкими суглинками, інколи сильно переробленими процесами крижанівського грунтоутворення. Загальна потужність 1,2-2,0м. Відклади кліматоліту часто у розрізах редуковані.

\section{Крижсанівський}

кліматоліт

представлений педогоризонтом, що складається переважно із двох викопних грунтів, зрідка - 3 трьох. Залежно від форм рельєфу грунти червонувато-бурі, світло-коричнювато-бурі за кольором, складені глиною тонкопилуватою, інколи $з$ ознаками гідроморфізму. На схилах грунтові відклади інколи опіщанені. Загальна потужність від 1,0 до 5 м.

Іллічівський кліматоліт - складений бурувато-сірою глиною, інколи 3 палевим відтінком, щільною, карбонатною. Потужність 0,4-0,5 м. У межах регіону досліджень відклади кліматоліту простежуються рідко.

Широкинський кліматоліт - поширений на вододільних просторах та в межах розвитку пліоценових i неоплейстоценових терас. Відсутній у схилових частинах балок та на плейстоценових терасах. Педогоризонт частіше за все представлений викопними грунтами двох оптимумів $\left(\mathrm{sh}_{1} \mathrm{i} \mathrm{sh}_{3}\right)$, розділених малопотужним прошарком лесоподібних глин $\left(\mathrm{sh}_{2}\right)$. Грунти коричневі, темно-коричневі, червонуватокоричневі, глинисті за гранулометричним складом, глибистої та грудкувато-призматичної структури. У нижній частині профілю гарно виражений карбонатний горизонт. Загальна потужність 1,5-4,0 м.

Нижній неоплейстоцен. Приазовський кліматоліт - складений оливково-жовтим лесоподібним суглинком, важкого, та середнього гранулометричного складу, часто карбонатним, 3 марганцевим дендритом. Потужність $0,1-1,0$ м. Частіше за все у розрізах мартоноські грунти накладаються на широкинські, утворюючи потужну коричнево-буру товщу, а сліди приазовського лесоподібного суглинку простежуються лише у вигляді окремих плям у підошві мартоноського педогоризонту.

\section{Мартоноський кліматоліт}

представлений педогоризонтом, що складається iз двох, інколи трьох викопних грунтів, розділених прошарками лесоподібних суглинків та глин. Грунти бурі та червонувато-бурі, важкосуглинисті, рідше глинисті, злиті (особливо оглеєні різновиди). Карбонатні горизонти грунтів слабко виражені. У деяких розрізах простежені елювіально-делювіальні грунтові відклади. Загальна потужність $0,5-2,0 \mathrm{M}$.

Сульський кліматоліт - представлений палевими суглинками, середніми до важких за гранулометричним складом, пухкими, макропористими, крупнопилуватими, карбонатними. Загальна потужність - до 2,0 м. На схилах лесоподібні суглинки часто бувають опіщанені.

Лубенський кліматоліт - представлений педогоризонтом, що складається із трьох викопних грунтів, розділених прошарками лесоподібних суглинків. Залежно від геоморфологічної експозиції грунти раннього оптимуму бурі, грунти пізнього оптимуму чорноземовидні i лугово-чорноземовидні, лугово-темно-сірі до чорних за кольором, грунти заключної стадії педогенезу сірувато- та cipoбурі. Всі грунти важкосуглинисті за гранулометричним складом. Характерна особливість грунтів верхньої частини лубенського розрізу - нерівна границя у вигляді тріщин, що глибоко проникають у грунт раннього оптимуму. Загальна потужність педогоризонту 0,5-3 м. 


\section{Тилігульський}

представлений лесовидним

кліматоліт

палево-коричневато-бурим

суглинком, середнім за гранулометричним складом, зрідка - лесом карбонатним. Часто перетворений процесами завадівського грунтоутворення. Потужність 0,3-1,0 м.

Відклади нижнього неоплейстоцену перекриваються середньонеоплейстоценовими породами, які в межах регіону досліджень розвинуті на вододілах та пологих схилах. На високих вододільних ділянках окремі горизонти (кайдацький, тясминський) не мають значного поширення та відрізняються скороченими потужностями. Найбільш представницькі серед середньонеоплейстоценових відкладів породи дніпровського кліматоліту. Відклади верхнього неоплейстоцену в межах регіону досліджень не дуже представницькі. У повному обсязі вони розвинуті лише на пологих схилах та в днищах балок.

Донецька складчаста споруда. Придонеиька рівнина. Згідно зі схемою районування четвертинних відкладів України (Stratigraficheskie skhemy dokembriya i fanerozoya Ukrainy, Redaktor Volodin, 1993), регіон досліджень відноситься до південної частини лесової області позальодовикової зони. Субаеральні відклади еоплейстоцену та нижнього неоплейстоцену регіону досліджень представлені викопними грунтами лесоподібними суглинками, що їх розділяють, підстилаються глинами та викопними грунтами верхього пліоцену та перекриваються завадівським педогоризонтом середнього неоплейстоцену.

Характерна особливість лесово-грунтової формації регіону - переважання в розрізах педогоризонтів. Горизонти лесовидних глин та лесів мають скорочені потужності, а в деяких розрізах узагалі редуковані, особливо це стосується іллічівського, приазовського та сульського кліматолітів.

Коротка літологічна характеристика кліматолітів.

Еоплейстоцен. Березанський кліматоліт представлений лесоподібними глинами, зрідка важкими суглинками, інколи запіщаненими, бурувато-світло-коричневими, оливковими 3 коричневими плямами, сизувато-бурими, інколи 3 одним ембріональним грунтом, карбонатними. Потужність 0,2-4,0 м. У розрізах часто редуковані внаслідок денудаційних процесів та переробки процесами грунтоутворення крижанівського часу.

Крижанівський

кліматолім

представлений педогоризонтом або грунтовими відкладами. Частіше за все у розрізах представлені двома грунтами, у повних розрізах - трьома. Нижні грунти червонувато-бурі за кольором, верхній грунт $\mathrm{kr}_{3}$ - червонуватокоричневий, глинистого складу, часто опіщанений. У нижній частині профілів грунтів чітко простежуються карбонатні горизонти. Загальна потужність 0,6-7,0 м.

Іллічівський кліматоліт - представлений глинами та важкими суглинками палево-бурого, інколи коричневого та сизувато-бурого кольору, карбонатними. Потужність $(0,2-1,6 \mathrm{M})$. Простежується в розрізах дуже рідко.

\section{Широкинський}

кліматолім

представлений педогоризонтом, що складається iз двох грунтів оптимумів, та лесоподібного прошарку, що їх розділяе. У повних розрізах (лівобережжя Сіверського Донця) та на понижених елементах рельєфу простежено два грунти раннього оптимуму: $\mathrm{sh}_{1 \mathrm{~b} 1}-$ бурий лісовий та $\mathrm{sh}_{1 \mathrm{~b} 2}$ - темно-коричневий, $\mathrm{sh}_{2}-$ прошарок лесоподібної глини, $\mathrm{sh}_{3}$ - коричневий та темнокоричневий 3 чітко вираженим карбонатним горизонтом. Грунти часто загіпсовані. Слід зазначити, що за палеопедологічними даними (Sirenko, Turlo, 1986) грунт $\mathrm{sh}_{3}$ розглядається як заключна стадія широкинського педогнезу, а палінологічні дані свідчать про те, що зазначений грунт формувався під час кліматичного оптимуму. Загальна потужність педогоризонту $0,5-5,5 \mathrm{~m}$.

\section{Нижній неоплейстоцен. Приазовський} кліматоліт - представлений лесоподібними суглинками важкими жовтувато-бурими, інколи піщанистими. Потужність $0,0-0,5$ м. Простежується не у всіх розрізах. Найбільш поширений у розрізах долини Сіверського Донця, де потужність його може збільшуватись до 4,0 м.

Мартоноський кліматоліт - у субаеральних фаціях представлений елювіальними та елювіально-делювіальними відкладами. Частіше за все простежуються елювіальні відклади, представлені педогоризонтом, що складається 3 трьох викопних грунтів, інколи розділених малопотужними $(0,2-0,3$ м) прошарками лесоподібних суглинків. Грунти бурого, червонувато-бурого кольору, важкосуглинисті (переважно другого оптимуму та заключної 
стадії педогенезу) і глинисті (ранній оптимум) за гранулометричним складом. Загальна потужність до 4,5 м.

Сульський кліматолім - представлений палево-сірувато-бурими лесоподібними суглинками, важкими за гранулометричним складом, зрідка середніми, часто опіщаненими. Потужність 0,3-1,3 м. Інколи у розрізах не простежується завдяки значному перетворенню процесами лубенського грунтоутворення.

Лубенський кліматолім - представлений педогоризонтом, що складається 3 трьох грунтів, розділених малопотужними $(0,20,4-\mathrm{M})$ прошарками лесоподібних суглинків. Грунти раннього оптимуму коричнювато-бурі, щільні, горіхуватої структури. Грунти пізнього оптимуму чорноземоподібні, лугові та глибоко проникають у нижні, завдяки чому грунти раннього оптимуму інколи трапляються лише у вигляді окремих буроколірних плям. Грунти заключної стадії педогенезу сірувато-коричневі за кольором, малопотужні $(0,4-0,5$ м), без чітко вираженої структури. За гранулометричним складом грунти важкосуглинисті, інколи опіщанені. Потужність залежно від рельєфу коливається в межах 1,0 - 4,5 м.

\section{Тилігульский}

\section{кліматолит}

представлений бурими, палево-бурими 3 коричневим відтінком лесоподібними суглинками, важкими за складом, опіщаненими, потужністю від 0,2 до 5,0 м. У південній та східній частинах регіону досліджень у розрізах часто редукований, а в центральній частині найбільш широко представлений серед нижньонеоплейстоценових лесоподібних суглинків.

Спорово-пилкові комплеси (СПК) із відкладів еоплейстоцену платформної України. СПК 3 березанського горизонту лісостепового та степового (для розрізів південних регіонів) типів. Характерна особливість - збіднення як пилку листяних деревних порід, так і трав'янистих рослин (переважно за рахунок пилкових зерен різнотрав'я). Серед пилку деревних порід домінують Pinus sp. subg. Diploxylon Koehne., $\boldsymbol{P}$. aff. sylvestris L. Широколисті породи помірнотеплої зони представлені переважно пилком Quercus cf. robur L. и Tilia cf. cordata Mill. (у сумі до 2,4 \%). У складі СПК, що характеризують породи центральної та північносхідної частин України кількість пилку деревних i трав'янистих порід перебуває майже у рівних співвідношеннях (розрізи ДДЗ та схилів УЩ), або останній дещо переважає (розрізи центральної частини УЩ). У складі спектрів із відкладів північно-західної частини ДДЗ відмічені поодинокі пилкові зерна Juglans cf. regia $\mathrm{L}$. та Moraceae.

У СПК 3 відкладів розрізів південних регіонів і Донбасу домінує пилок трав'янистих рослин, що належить переважно до таксонів родин Chenopodiaceae та Asteraceae'.

Для розрізів південно-східних регіонів характерна присутність значної кількості галоксерофітів Frankeniaceae (Sirenko, Turlo, 1986). За матеріалами Н. П. Герасименко (Gerasymenko, 2004) у складі встановленого СПК для північної та центральної частин України можливо виділити три підкомплекси. Перший ma третій - характеризують нижню та верхню частини розрізу березанських відкладів i відрізняються збідненим таксономічним складом, а другий - відповідає ембріональному грунту середньої частини розрізу березанських відкладів і відрізняється появою пилку Picea, а також деяким збільшенням ролі та таксономічної різноманітності пилку листяних рослин.

\section{СПК 3 крижанівського педогоризонту} переважно лісового, зрідка лісостепового і дуже рідко (Донбас) степового типів. Від СПК 3 берегівського кліматоліту верхнього пліоцену відрізняється зростанням ролі пилку деревних порід, переважно за рахунок Pinus sp. subg. Diploxylon Koehne.i Betula spp;; скороченням кількості та таксономічного різноманіття пилку термофільних рослин $(1,5-2,8 \%)$, що належить переважно Juglans spp., інколи Moraceae і дуже рідко - Pterocarya cf. stenoptera L., Vitis sp. Характерна особливість встановленого комплексу - присутність у спектрах із відкладів увсіх вивчених розрізів пилку Picea.

У складі встановленого комплексу частіше за все виділяються два підкомплекси, що відповідають грунтам раннього та пізнього оптимумів крижанівського педогенезу, в СПК 3 відкладів найбільш повних розрізів - три. Залежно від геоморфологічного та географічного розташування розрізів співвідношення пилку деревних порід та трав'янистих рослин у межах установлених підкомплексів можуть змінюватись.

Перший - характеризує грунт раннього оптимуму. Відрізняється незначним вмістом та таксономічним різноманіттям пилку листяних рослин, домінуванням пилкових зерен Pinus spp. У спектрах відкладів більшості розрізів

\footnotetext{
1 * Жирним шрифтом виділені характерні таксони
} 
зафіксовано найменшу кількість пилку деревних порід та найбільше представництво пилкових зерен трав'янистих рослин.

Другий - характеризує грунт пізнього оптимуму та порівняно 3 першим, відрізняється зростаням вмісту пилку всіх груп листяних рослин у складі спектрів, особливо дрібнолистих порід. Як домінанти серед пилку широколистих порід помірно-теплої зони виступають переважно Quercus cf. robur L. і Quercus cf. pubescens Willd., у СПК деяких розрізів - Tilia cf. cordata Mill. Визначені також пилкові зерна Fagus cf. sylvatica L., Fagus sp., T. cf. platyphyllos Scop., T. cf. rubra DC., Carpinus cf. betulus L., C. cf. orientalis Mill., Ulmus cf. laevis Pall., Ulmus spp., Elaeagnus sp. До складу СПК відкладів розрізів південних регіонів входять пилкові зерна Pterocarya cf. stenoptera L., Juglans cf. nigra L., Acer sp., Myrica sp., Tamaricaceae, чагарники представлені переважно пилком Corylus spp., інколи зустрічаються-Rhamnus sp., Euonymus sp.

Tретій - характеризує самий верхній грунт педогоризонту і відрізняється збідненим таксономічним складом пилку листяних рослин, скороченням кількості пилкових зерен широколистих порід помірно-теплої зони, представлених переважно Quercus cf. robur L. та Corulus cf. avellana L., а також відсутністю пилку термофільних рослин.

СПК з іллічівського горизонту лісостепового (3 переважанням пилку трав'янистих рослин) та степового типів. Серед пилку деревних порід домінують Pinus sp. sect. Eupitys Spach., у тому числі $\boldsymbol{P}$. aff. sylvestris L., 3 незначною участю Betula spp. та поодинокими Alnus spp. Пилок широколистих порід (до $1,8 \%$ ) належить переважно Quercus cf. robur L. і лише у СПК 3 відкладів Закарпаття (Gerasymenko, 2004) та Донбасу (Gerasymenko, 2004, Sirenko,Turlo, 1986.) дещо розширюється його таксономічний склад. Пилок трав'янистих рослин представлений в основному таксонами родин Chenopodiaceae, Asteraceae та Poaceae.

СПК 3 широкинського педогоризонту переважно лісостепового, інколи лісового типів (північна частина УЩ, північно-західна частина ДД3). До відмінних рис можливо зачислити високий відсоток вмісту пилку листяних рослин, у тому числі широколистих порід помірно-теплої зони: Quercus ef. pubescens Willd., $Q$. cf. robur L., Quercus sp., Fagus cf. sylvatica L., F. cf. orientalis Lipsky., Castanea sp., Tilia cf. cordata Mill., T. cf. platyphyllos Scop., T. cf. dasystyla
Stew., Tilia sp., Carpinus cf. betulus L., Ulmus cf. laevis Pall., Elaeagnus sp., Corylus spp., та листяних рослин помірної зони: Betula verrucosa Ehrh., B pubescens Ehrh., Betula. sp., Alnus cf. glutinosa (L.) Gaertn., Alnus sp., a також термофільних рослин: Juglans cf. cinerea L., J. cf. regia L., Pterocarya sp., Moraceae, для СПК 3 відкладів південних регіонів додатково Juglans cf. sieboldiana Maxim., J. cf. mollis Engelm., Rhus sp.; присутність пилку Pinus longifoliaformis Zak1., та - Pinus sp. sect. Strobus Schaw., P. sp. sect. Cembrae Spach.; помітне таксономічне різноманіття та значний процентний вміст пилку різнотрав'я; присутність спор: Polypodiaceae, Sphagnum sp., Lycopodium sp.

У складі комплексу чітко простежуються три підкомплекси:

Перший - характеризує грунти раннього оптимуму широкинського педогенезу. Відрізняєтся найвищим вмістом пилку деревних порід, а також спорових.

Другий - відповідає прошарку лесоподібної глини, що розділяє грунти раннього та пізнього оптимумів.

До відмінних особливостей можливо зачислити: переважання у складі спектрів пилку трав'янистих рослин, що належить переважно таксонам родин Chenopodiaceae та Asteraceae, або пилку Pinus spp. (північно-західна частина ДД3); збіднення таксономічного складу листяних рослин, помітне скорочення пилку термофільних рослин (менше $1 \%$ ), або його повне зникнення.

Третій - характеризує грунт пізнього оптимуму. В його складі зафіксовано майже рівну кількість пилку деревних та трав'янистих рослин, або зростання ролі пилку трав'янистих рослин у складі спектрів лісового типу (північна частина УЩ, північно-західна частина ДДЗ); найвищий процент участі та таксономічне різноманіття пилку мезофільного різнотрав'я: Apiaceae, Ranunculaceae, Lamiaceae, Fabaceae, Plantaginaceae, Polygonaceae, Rosaceae.

СПК 3 відкладів нижнього неоплейстоцену. СПК з приазовського горизонту степового та лісостепового типів із переважанням пилку трв'янистих рослин (центральна частина та схили УЩ). Серед пилку деревних порід домінує Pinus aff. sylvestris L. Пилок листяних рослин належить переважно Betula spp., поодиноко Quercus cf. robur L. і лише у складі СПК відкладів Середнього Придніпров'я (Sirenko, Turlo, 1986.) зафіксовано пилкові зерна Ulmus sp. i Corylus sp. Як домінанти групи пилку 
трав'янистих рослин встановлені Artemisia spp. і Chenopodiaceae. Пилок Роасеае та різнотрав'я зафіксований у меншій кількості.

СПК 3 мартоноського педогоризонту, переважно лісового типу (пилок деревних порід у його складі інколи досягає 80 \%), і лише для відкладів Донбасу та південних регіонів України встановлений лісостеповий тип. До відмінних особливостей можливо зачислити високий вміст та значне таксономічне різноманіття пилку деревних рослин, найбільш значний вміст пилку Pinus spp.: Pinus spp. subg. Diploxylon Koehne. (переважають), P. longifoliaformis Zakl., P. sp. sect. Strobus Schaw., $P$. sp. sect. Cembrae Spach.; присутність у складі комплексу 3 відкладів деяких розрізів пилку Picea sp sect. Eupicea Willkm.; найбільшу, серед СПК 3 нижньонеоплейстоценових відкладів, таксономічну різноманітність пилку листяних порід, причому як рослин помірної зони: Betula spp., Alnus spp., Salix spp., так і помірно-теплої зони: Quercus cf. robur L., Q. cf. pubescens Willd., Quercus sp., Fagus ef. sylvatica L., Fagus sp., Tilia cf. cordata Mill., T. cf. platyphyllos Scop., T. cf. dasystyla Stew., Tilia sp., Carpinus cf. betulus L., C. cf. orientalis Mill., Ulmus cf. laevis Pall., Ulmus spp., Rhamnus sp., Corylus sp., а в СПК з відкладів південних розрізів (Sirenko, Turlo, 1986) пилкових зерен Castanea sp.; значна участь та видове різноманіття пилку термофільних рослин; Juglans cf. cinerea L.; J. cf. nigra L.; Juglans cf. regia L., Juglans sp., Pterocarya cf. stenoptera D.S., Pterocarya spp., Moraceae; незначний вміст пилку трав'янистих рослин, присутність спор Polypodiaceae, Sphagnum sp., Lycopodium sp., Bryales.

У складі встановленого комплексу не завжди виділяються підкомплекси. Для СПК мартоноських відкладів найбільш повних розрізів Донбасу встановлено чотири підкомплекси, деякі 3 них простежені в ряді розрізів Волино-Подільської плити, північнозахідної частини ДДЗ та центральної частини УЩ.

Перший - відповідає грунту раннього оптимуму мартоноського педогенезу та відрізняється найвищим вмістом пилку деревних порід, а серед цієї групи - Pinus spp.

Другий - встановлений для грунту пізнього оптимуму і характеризується найвищою участю пилку широколистих рослин помірно-теплої зони і термофільних порід, а також деяким зростанням ролі пилку трав'янистих рослин.
У складі третього, що відповідає грунту заключної стадії педогенезу, зростає вміст пилку рослин помірної зони, а також скорочується участь пилку термофільних рослин.

Четвертий - встановлений поки лише у складі СПК з мартоноських відкладів Донбасу та північно-західної частини ДДЗ, характеризує лесоподібні прошарки, що розділяють грунти раннього та пізнього оптимумів, а також пізнього оптимуму і заключної стадії грунтоутворення. До основних відмінних особливостей можливо віднести такі: помітне збіднення таксономічного складу пилку i зростання кількості пилкових зерен трав'янистих рослин, особливо за рахунок Chenopodiaceae i Asteraceae (Донбас), а також пилковых зерен Pinus spp. subg. Diploxylon Koehne., Betula spp. (північно-західна частина ДДЗ).

СПК 3 сульского горизонту - переважно лісостепового, для порід Донбасу і південних регіонів України - степового, північної частини УЩ та Волино-Подільської плити - лісового типів. До відмінних особливостей можливо віднести: помітне збіднення таксономічного складу пилку деревних порід, представленого переважно Pinus spp. subg. Diploxylon Koehne., P. sp. sect. Eupitys Spach.,, Betula sp. sect Alba, Betula sp. sect Fruticosae et N.p., Alnus sp., Alnaster spp., інколи - Tilia cf. cordata Mill., Quercus cf. robur L., Ulmus sp., Corylus sp.; присутність у складі спектрів, що характеризують сульські відклади деяких розрізів, пилку Tilia cf. platyphyllos Scop., Juglans sp. (розріз біля м. Коростишів, північна частина УЩ; розріз біля с. Кайтанівка (УЩ), північно-західна частина ДДЗ, ВолиноПодільська плита (Sirenko, 2010)); переважання у групі трав'янистих рослин пилку таксонів родин Asteraceae, Chenopodiaceae та роду Artemisia sp.; практично повна відсутність спор.

У найбільш повних розрізах встановлено два підкомплекси:

Перший - характеризує нижню частину розрізу сульських відкладів і відрізняється незначним переважанням у складі спектрів пилку деревних порід, головним чином Pinus spp. subg. Diploxylon Koehne., найвищим вмістом пилку Betula і присутністю поодиноких пилкових зерен широколистих порід.

Другий - відповідає верхній частині розрізу і характеризується деяким збільшенням вмісту пилку трав'янистих рослин, а в цій групі пилкових зерен різнотрав'я і зростанням ролі 
пилку дрібнолистих порід, переважно за рахунок Alnaster spp.

СПК з лубенського педогоризонту переважно лісостепового типу, для відкладів північної частини УЩ і Волино-Подільської плити лісового. До відмінних рис можливо віднести: значну участь і таксономічну різноманітність у складі спектрів пилку трав'янистих рослин, а серед цієї групи - мезофільного різнотрав'я: Brassicaceae, Fabaceae, Lamiaceae, Ranunculaceae, Rosaceae Polygonaceae, Plantaginaceae, Scrophulariaceae; невисокий вміст (до 1,8\%) пилку термофільних рослин: Juglans cf. cinerea L., Juglans cf. regia L., Juglans. sp., а у відкладах деяких розрізів і повну його відсутність; значну кількість пилку листяних рослин, що належить переважно Betula sp. sect. Albae, Quercus cf. robur L., Tilia cf. cordata Mill., Ulmus cf. laevis Pall., Corylus cf. avellana L. та скорочення його таксономічної різноманітності порівняно 3 широкинським i мартоноським комплексами: (пилкові зерна Alnus spp., Fraxinus sp., Carpinus cf. betulus L., Fagus sp., T. cf. platyphyllos Scop., T. cf. rubra D.C., Elaeagnus sp., Rhamnus sp. зустрічаються рідко, та в незначній кількості); помітне зниження вмісту пилку Pinus spp. subg. Haploxylon Koehne. і зростання ролі Pinus spp. subg. Diploxylon Koehne, у тому числі - Pinus longifoliaformis Zak1.; присутність у складі комплексів відкладів деяких розрізів пилку Picea spp. та спор Polypodiaceae, Sphagnum sp., Lycopodium sp., Bryales.

Встановлено чотири підкомплекси.

Перший - характризує нижню частину лубенського педогоризонту. У його складі зафіксовано найвищий вміст пилку деревних рослин, переважно за рахунок Pinus spp. subg. Diploxylon Koehne., а також пилку листяних рослин помірної зони і доволі високий вміст пилку різнотрав'я, присутність пилкових зерен термофільних рослин.

Другий - характеризує пізньооптимальні грунти педогоризонту i відрізняється найширшим представництвом пилку трав'янистих рослин, переважно за рахунок Asteraceae, та деяким зростанням ролі пилку широколистих рослин помірно-теплої зони, переважно за рахунок Quercus cf. robur L. і Tilia cf. cordata Mill.

Третій - відповідає грунту заключної стадії педогенезу (верхня частина педогоризонту) і характеризується зростанням вмісту пилку рослин помірної зони та хвойних, повним зникненням пилкових зерен термофільних рослин, скороченням кількості та таксономічної різноманітності пилку різнотрав'я. Четвертий встановлений лише для лубенських відкладів розрізів ДД3 та Донбасу (як найбільш представницьких серед усіх вивчених), характеризує лесоподібні прошарки між окремими грунтами педогоризонту. Відрізняється помітним скороченням ролі пилку широколистих порід помірно-теплої зони та відсутністю пилку термофільних елементів.

СПК з тилігульского горизонту лісостепового (ДД3, центральна частина УЩ), степового (Донбас, Приазов'я) типів. Відмінні особливості: переважання у складі спектрів пилку трав'янистих рослин, збіднений таксономічний склад пилку як деревних, так і трав'янистих рослин: Pinus sp. sect. Eupitys Spach., P. aff. sylvestris L., Betula sp. sect Fruticosae et $N$., Alnus sp., Alnaster sp., Quercus cf. robur L., Chenopodiaceae, Asteraceae, Artemisia spp., Poасеаe, різнотрав'я.

У найбільш повних розрізах встановлено три підкомплекси:

Перший - характеризує саму нижню частину тилігульських відкладів і відрізняється найбільш високим вмістом пилку Pinus i поодинокими знахідками пилкових зерен листяних деревних порід.

Другий - характеризує малопотужний ембріональний грунт і відрізняється присутністю невеликої кількості (у сумі до $3 \%$ ) пилкових зерен Tilia cf. cordata Mill., Quercus cf. robur L., Corylus cf. avellana L., а також збільшенням ролі пилку різнотрав'я.

Третій - відповідає верхній частині розрізу тилігульських відкладів i характеризується найвищою кількістю пилку Asteraceae, Chenopodiaceae та Artemisia sp., i найменшою - деревних порід.

Висновки. За результатами проведених досліджень встановлено дев'ять споровопилкових комплексів для кожного кліматоліту еоплейстоцену та нижнього неоплейстоцену рівнинної частини України. Короткий опис встановлених комплексів запропонований до характеристики кліматолітів Модернізованої стратиграфічної схеми четвертинних відкладів України. У Схемі четвертинних відкладів 1993 р. палінологічні дані наведені у графічній формі. Автором запропоновано для кожного кліматоліту еоплейстоценового та нижнього неоплейстоценового розрізу встановити СПК (Табл.), що відрізняються один від одного за типом, співвідношеннями основних груп пилку 
та спор (деревних порід, трав'янистих рослин i спорових), співвідношеннями серед встановлених груп (пилку хвойних і листяних порід, листяних порід помірної та помірно-теплої зони), а також - характерних таксонів; кількості та ступеня участі у складі СПК термофільних елементів. У складі кожного СПК встановлено підкомплекси, що відповідають грунтам окремих стадій в межах педогоризонтів.

Встановлено, що закономірності зміни таких підкомплексів у складі СПК кожного кліматоліту індивідуальні та слугують основою для стратифікації та кореляції досліджених відкладів, а також є підставою для реконструкції фаз розвитку рослинності, показаних на Табл. Колонка фаз розвитку рослинності запропонована автором у зв'язку з тим, що при стратифікації відкладів плейстоцену особливо важливо враховувати послідовності змін складу рослинності у часі. Численними палінологічними дослідженнями плейстоценових відкладів Білорусі (Elovicheva, 2001.), Росіï (Bolihovskaja, 1995), України (Gerasymenko, 2004, Sirenko, 2012) встановлено, що кожному теплому етапу плейстоцену відповідає своя послідовність фаз та підфаз розвитку рослинності. Такі послідовності i використані як основні для кореляції одновікових відкладів у межах різних регіонів України.

Зазначимо, що у Схемі 1993 р. широкинський та приазовський кліматоліти розглядались у складі нижнього неоплейстоцену, a у запропонованому автором варіанті (Табл.) Схеми широкинський кліматоліт включений до еоплейстоцену. На користь такого рішення свідчать i матеріали палеопедологічних досліджень, згідно 3 якими під час вивчення розрізу знизу доверху це останній педогоризонт, що за гранулометричним складом представлений глинами

Згідно із сучасними уявленнями про палеомагнітну шкалу плейстоцену (Stratygrafichnyj kodeks Ukrai'ny Redaktor P.F. Gozhyk, 2012) границя ортозон Брюнес-Матуяма проходить у мартоноському педогоризонті, а не в широкинському, як це було прийнято раніше. Результати проведених палінологічних досліджень також не суперечать наведеним даним.

Палеоботанічні матеріали свідчать про відносно більш посушливі умови, що існували в еоплейстоцені, порівняно 3 пізнім пліоценом та раннім неоплейстоценом. Широкинські флори мають перехідний характер від еоплейстоценових

до

нижньонеоплейстоценових. За кількістю термофільних елементів вони часто переважають мартоноські, але за таксономічною різноманітністю листяних деревних порід значно поступаються останнім. Слід також взяти до уваги зміну типу СПК від лісостепового для відкладів широкинського кліматоліту до лісового для СПК мартоноського. Ця відмінність особливо яскраво простежується у розрізах 3 редукцією приазовського лесу.

У зв'язку з редукцією приазовського лесу в більшості розрізів північно-східної, західної та центральної частин України, на сучасному етапі досліджень не вдалось отримати його повну та детальну палінологічну характеристику i розташування цього кліматоліту у Схемі поки може бути встановлене лише за літологічними даними. На думку автора, нечисленні матеріали палінологічних досліджень приазовських відкладів, що представлені у сучасних публікаціях, можуть свідчити на користь віднесення приазовського кліматоліту до нижнього неоплейстоцену. Але таких даних поки недостатньо, тому у запропонованому варіанті Схеми автор залишає це питання відкритим.

Нижня границя плейстоцену приймається на рівні 1,8 млн років. Детальне палінологічне обгрунтування цього рішення складає предмет окремої публікації.

Підсумовуючи отримані результати, можна стверджувати, що наведені матеріали сприятимуть більш широкому використанню палінологічних даних для стратиграфічних побудов. Отримані матеріали вже використані для обгрунтування віку плейстоценових відкладів у межах територій аркушів геологічної зйомки м-бу 1 : 200 000: «Маріуполь», «Сміла», «Новоукраїнка», «Знам’янка», «Кіровоград», «Фастів» та «Черкаси».

\section{Бібліографічні посилання}

Artjushenko A.T., 1970. Rastitel'nost' Lesostepi i Stepi Ukrainy $\mathrm{v}$ chetvertichnom periode [Vegetation of the Forest-Steppe and Steppe of Ukraine in Quaternary] Nauk. dumka, Kiev. 173 s. (in Russian).

Artjushenko A.T., Pashkevich G.A., Parishkura S.I., Kareva E.V., 1973. Paleobotanicheskaja harakteristika opornyh razrezov chetvertichnyh (antropogenovyh) otlozhenij srednej i juzhnoj chasti Ukrainy [Palebotanical characteristic of the reference sections of Quaternary deposits Middle and 
Southern parts of Ukraine] Nauk. Dumka, Kiev. 95 s. (in Russian).

Boguckij A.B., 1987. Osnovnye lessovye i paleopochvennye gorizonty perigljacial'noj lessovo-pochvennoj serii plejstocena na jugozapade Vostochno-Evropejskoj platformy [The main loess and paleo-soil horizons of the periglacial loess-soil series of the Pleistocene in the southwest of the East European Platform] Stratigrafija i korreljacija morskih i kontinental'nyh otlozhenij Ukrainy. Nauk. dumka, Kiev. 47-52 (in Russian).

Boguc'kij A.B., Boguc'ki O.A., Voloshin P. K., 1998. Lesovij pokriv Volins'koï visochini [Loess cover of Volyn Upland] Ukraïns'ke Polissja: vchora, s'ogodni, zavtra: zb. nauk. prac', Luc'k: Nadstir'ja, 105-107 (in Ukrainian).

Bolihovskaja N.S., 1995 Jevoljucija lessovopochvennoj formacii Severnoj Evrazii. [Evolution of the loess-soil formation of Northern Eurasia] Izd-vo Mosk. un-ta., Moskva. 270 s. (in Russian).

Veklich M.F., Sirenko N.A., 1976. Pliocen i plejstocen levoberezh'ja nizhnego Dnepra i Ravninnogo Kryma [Pliocene and Pleistocene of Left bank of the Lower Dnieper and Plain Crimea] Nauk. dumka, Kiev. 187 s. (in Russian).

Veklich M.F., 1982. Paleojetapnost' i stratotipy pochvennyh formacij verhnego kajnozoja Ukrainy [Paleo-stages and stratotypes of soil formations of the Upper Cenozoic] Nauk. Dumka, Kiev. 202 s. (in Rassian).

Veklich M.F., Sirenko N.A., Matviishina Zh.N. i dr., 1984. Paleogeografija Kievskogo Pridneprov'ja. [Paleogeography of the Kiev Dnieper] Nauk.dumka, Kiev. 176 s. (in Russian).

Gerasymenko N.P., 2004. Rozvytok zonal'nyh landshaftiv chetvertynnogo periodu na terrytorii' Ukrai'ny [Development of zonal landscapes of Quaternary in the territory of Ukraine] avtoref. dys. na soyskanye nauchn. stepeny dokt. heogr. nauk.: spets. 11.00.04 «Geomorfology and paleogeography» Kiev. 40 s. (in Ukrainian).

Elovicheva Ja.K., 2001. Jevoljucija prirodnoj sredy atnropogena Belarusi (po palinologicheskih dannym) [Evolution of the natural environment of the Atropropogen of Belarus (according to palynological data] BELSJeNS, Minsk. 292 s. (in Russian).
Matviishyna Zh.M., Gerasymenko N.P., Perederii V.I., Brahin A.M., Ivchenko A.S., Karmazynenko S.P., Nahirnyi V.M., Parkhomenko O.H, 2010. Prostorovo-chasova koreljacija paleogeografichnih umov chetvertinnogo periodu na teritorii Ukraïni. [Spatio-temporal correlation of Quaternary paleogeographic conditions in Ukraine] Nauk. dumka, Kiev. 191 s. (in Ukrainian).

Sirenko O.A., 1994. Osoblyvosti rozvytku roslynnosti na shodi Ukrai'ny $\mathrm{v}$ rann'omu ta seredn'omu neoplejstoceni [Peculiarities of the vegetation development in early and middle Neopleystocene of Eastern Ukraine] Ukrainsky botan. zhurnal. 51, 6. 45-51. (in Ukrainian).

Sirenko O.A., 2002. Zminy roslynnogo pokryvu Zhytomyrs'kogo Polissja protjagom rann'ogo ta seredn'ogo neoplejstocenu (za palinologichnymy danymy) [Changes of vegetation cover in Zhytomyr Polissya during the Early and Middle Neopleystocene (by palynological data)] Paleontol. zb. 34, 104111 (in Ukrainian).

Sirenko O.A. Bahmutov V.G., Nikitchenko I.M., 2008. Novi materiali do vivchennja neoplejstocenovih vidkladiv pozal'odovikovoï zoni Ukraïns'kogo shhita [New data for studing Neopleistocene deposits of Nonglacial zone of the Ukrainian Shield]. Geologichnij zhurnal. 4 (325). 113-122. (in Ukrainian).

Sirenko E.A., 2009a. Fitostratigraficheskij aspekt izuchenija verhnepliocenovyhneoplejstocenovyh otlozhenij Ukrainskogo shhita. [Phytostratigraphic aspects of studying the Upper Pliocene-Neopleistocene deposits of the Ukrainian Shield]. Geologichnij zhurnal. 3. 65-78. (in Russian).

Sirenko O.A., 2009b. Palinologichni dani do stratigrafiï nizhn'oneoplejstocenovih vidkladiv Volino-Podil's'koï pliti. [Palynological evidences on stratigraphy of the lower Neopleistocene sediments of the VolynPodolia Plate]. Najdavnishi lesi Podillja i Pokuttja: problemi genezi, stratigrafiï, paleogeografiii: $z b$. nauk. prac' do XVI ukraïns'ko-pol's'kogo seminaru, (SkalaPodil's'ka, 13-16 veresnja 2009 r.) LNU, L'viv. 97-113. (in Ukrainian).

Sirenko E.A., 2010. Novye palinologicheskie dannye o sostave rastitel'nosti sul'skogo jetapa rannego neoplejstocena lesostepnoj zony Ukrainy. [New palynological data on the 
vegetation composition during the Sula stage of the Early Neopleistocene forest-steppe zone of Ukraine]. Geologichnij zhurnal. №1. 86-91. (in Russian)

Sirenko O.A., 2011. Palinologichni kriteriï stratigrafichnogo rozchlenuvannja vidkladiv verhn'ogo pliocenu-nizhn'ogo neoplejstocenu platformnoï Ukraïni. [Palynological criteria for stratigraphik separation of Upper Pliocene-Lower Neopleistocene deposits of the platform Ukraine] Paleontol. zb. 43. 2328. (in Ukrainian).

Sirenko O.A., 2012. Palinostratyhrafiya kontynental' nykh verkhn'opliotsenovykhnyzhn'oneopleystotsenovykh vidkladiv pivdennoyi chastyny Skhidno-Yevropeys'koyi platformy: avtoref. dys. na soyskanye nauchn. stepeny dokt. heol. nauk.: spets. 04.00.09 «paleontolohyya y stratyhrafyya» [Palynostratigraphy of Continental Upper Pliocene - Lower Neopleistocene Deposits of Southern Part of the East European Platform]. Kiev. 43 s. (in Ukrainian).Sirenko N.A. Turlo S.I., 1986. Razvitie pochv i rastitel'nosti Ukrainy $\mathrm{v}$ pliotsene i pleystotsene [The development of soil and vegetation of Ukraine in the Pliocene and Pleistocene]. Nauk. dumka, Kiev. 187 s. (in Russian)
Stratygrafichnyj kodeks Ukrai'ny Redaktor P.F. Gozhyk. 2012, [Stratigraphic Code of Ukarine, P.F. Gozhyk (Editor-in-Chief)]. Kiev. 66 s. (in Ukrainian).

Stratigraficheskie skhemy dokembriya i fanerozoya Ukrainy Redaktor D.F. Volodin, 1993. [Stratigraphic schemes of Precambrian and Phanerozoic of Ukraine] Kiev. Geoprognoz (in Russian).

Tretjak A.N. Vigiljanskaja L.I., 1994. Magnitostratigraficheskaja shkala plejstocena Ukrainy [Magnetostratigraphic scale of the Pleistocene of Ukraine] Geofizicheskij zhurnal. 16, 2. 3-14. (in Russian).

Shelkopljas V.N., Gozhik P.F., Hristoforova T.F. i dr., 1986. Antropogenovye otlozhenija Ukrainy. [Anthropogenic deposits of Ukraine]. Nauk. dumka, Kiev. 152 s. (in Russian).

Shovkopljas V., Vozgrin B., Hristoforova T. , 2011. Pro davni l'odoviki Volini [On ancient glaciers ef Volyn] Gljacial i perigljacial Ukraïns'kogo Peredkarpattja: zb.nauk prac' do XVII ukr. - pol's'k. seminaru m. Sambir, Ukraïna, 15-18 veresnja 2011 r., LNU, L'viv. 195-200. (in Ukrainian).

Надійшла до редколегії 24.04.2017 p 